\title{
The Empowerment of Households towards Independence through Social Capital in Program Keluarga Harapan (PKH)
}

\section{Widia Lestari 1,* (D), Drajat Tri Kartono ${ }^{1}$ (D), Argyo Demartoto ${ }^{1}$ (D), and Khabib Bima Setiyawan 1 (D)}

${ }^{1}$ Department of Sociology, Faculty of Social and Political Sciences, Sebelas Maret University, 57126, Surakarta, Central Java Province, Indonesia.

*Corresponding Author: widiayayak@gmail.com

\section{ARTICLE INFO}

Publication Info:

Research Article

How to cite:

Lestari, W., Kartono, D. T., Demartoto, A., E Setiyawan, K. B. (2019). The Empowerment of Households towards Independence through Social Capital in Program Keluarga Harapan (PKH). Society, 7(2), 268-280.

DOI : 10.33019/society.v7i2.124

Copyright (C) 2019. Owned by Author(s), published by Society

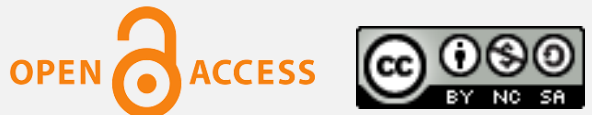

This is an open access article.

License: Attribution-

NonCommercial-ShareAlike (CC BY-NC-SA)

\section{ABSTRACT}

This research aims to reveal 1) The Role of Program Keluarga Harapan or known as PKH (Family of Hope Program) in empowering beneficiary households or known as KPM (Keluarga Penerima Manfaat), 2) The Role of Social Capital in realizing the independence of KPM-PKH in Sukoharjo district, Central Java Province, Indonesia. This research was qualitative by using a case study approach. The determination of informants used a purposive sampling technique. The informants were eight beneficiary households and four key informants they were the Head of Sukoharjo district office of the Ministry of Social Services, coordinator of Sukoharjo district, PKH supervisor, PKH facilitator, and two key informants to support any information. Data were collected through observation, interviews, and documentation. The data were analyzed into three stages; data reduction, data display, and conclusion drawing. The data were verified by observation and source triangulation and time. The result showed that 1) The Role of PKH in empowering the beneficiary households by providing social assistance, strengthening by the regular meeting of Family Development Session, known as P2K2 (Pertemuan Peningkatan Kemampuan Keluarga), strengthening by PKH cooperative, and joint business group, known as KUBE (Kelompok Usaha Bersama), 2) The Role of social capital to build independence of KPM-PKH by adopting cultural values, trust, reciprocity, participation, communication system, and venture networks of beneficiary households. This is caused by the relevance of social bonding, social bridging, and social linking carried out by KPM-PKH. To conclude, livelihoods choice of KPM-PKH by employing

Copyright (C) 2019. Owned by Author(s), published by Society. This is an open access article under CC-BY-NC-SA license. 
Received: November 15, 2019; Accepted: December 28, 2019; Published: December 31, 2019; social capital becomes strategic and productive opportunities to empower independence among poor households as the beneficiary of PKH.

\section{Keywords: Empowerment; Household; Independence; $\mathrm{PKH}$; Social Capital}

\section{Introduction}

Program Keluarga Harapan or known as PKH (Family of Hope Program) is Indonesia's Conditional Cash Transfer (CCT) program which first piloted in 2007. The main target of PKH is to reduce poverty in Indonesia. As a result, the number of poor people in Indonesia in 2018 has decreased from 10, 12\% in September 2017 to 9.82\% in March 2018 of the total population of Indonesia (Badan Pusat Statistik, 2018).

As conditional assistance, PKH social assistance is only given to poor households, who have school children, toddlers, pregnant women, the elderly and people with disabilities. The program is to improve the lives of beneficiary households, known as KPM (Keluarga Penerima Manfaat), in accessing basic social services in health, education, food and nutrition, care and assistance, including access to various other social protection programs that are complementary sustainably. PKH aims to be the main poverty alleviation program that synergizes various national social protection and empowerment programs (Dulkiah et al., 2018; Habibullah, 2017).

Various improvements of the PKH program have been carried out including enhancing the $\mathrm{PKH}$ business, expanding the target beneficiaries, and strengthening complementary programs (Cahyadi et al., 2018). PKH beneficiary households must be certain to have received Non-Cash Food Assistance (BPNT), Healthy Indonesia Card (KIS), Smart Indonesia Card (KIP), Uninhabitable Home Assistance (Rutilahu), Empowerment through Joint Business Groups (KUBE) including various programs other social protection and empowerment. It aims to make poor households get out of poverty immediately and become prosperous (Permana et al., 2018).

The running of PKH for 11 years is considered a success is seen from the number of independent prosperous graduation (Graduasi Mandiri Sejahtera). This means that the beneficiaries of PKH are able, both economically and independently, to provide for the necessities of life that include food, health, and education. In 2017 there were 230,351 KPM-PKH graduated or 2.3 percent of the total 6 million participants. In 2018 there were 621,789 KPMPKH graduated or 6.21 percent of the total 10 million participants. Whereas in 2019 , the target is 800,000 KPM-PKH graduated or 8 percent of the total 10 million participants (Kholis, 2019).

This achievement makes the PKH program very important in empowering households towards independence as an effort to reduce poverty. Thus, the meaning of social assistance is not just a contribution but rather towards the empowerment of the poor to create independence. According to research conducted by Habibullah (2017), PKH assistance was used to meet education costs, health costs/nutrition improvement, and other needs. This is following the objectives of $\mathrm{PKH}$, namely improving human quality (HR), creating quality generations, being able to compete in accessing jobs and being the subject of development (Simanjuntak et al., 2010; Alatas et al., 2011).

The success of PKH is a social phenomenon in the effort to eradicate poverty by the Indonesian government. This is supported by previous research, as Lobo (2019) showed that $\mathrm{PKH}$ is an empowerment of the poor households that have been succeeded in the Papua region.

Copyright (C 2019. Owned by Author(s), published by Society. This is an open access article under CC-BY-NC-SA license.

https://doi.org/10.33019/society.v7i2.124 
Luthfi (2019) showed that PKH assistance helped the socio-economic conditions, health, and education of children of poor households, and made PKH participants aware of the importance of education and health services to improve community welfare. Septiani et al., (2019) showed that there was a significant role between PKH facilitators in helping independence and family welfare. The more the performance of $\mathrm{PKH}$ facilitators is improved, the better it is in helping the independence and welfare of the family.

The running of $\mathrm{PKH}$ received a positive response from several previous studies. Starting from a program that only provides free social assistance, over time, PKH can turn into assistance that empowers and encourages independence. This change was based on program innovation and the persistence of $\mathrm{PKH}$ beneficiary households in managing aid. Therefore this research interested in studying more deeply the role of $\mathrm{PKH}$ in empowering beneficiary households and the role of social capital in realizing the independence of the beneficiary households.

\section{Literature Review}

Social capital refers to the capacity of individuals to obtain material or symbolic goods of value based on social relations virtue and membership in a social group or the capacity of people plurality to enjoy the collective benefits action based on the virtues of social participation, trust in institutions or commitment to establish ways of doing things (Ritzer, 2004).

According to Portes (1998), social capital is the ability of actors to guarantee benefits by relying on membership in social networks and other social structures. On the other hand, Woolcock (2001) stated that social capital is the degree of social cohesion in a community. It refers to processes among people who build networks, norms, social trust and facilitate coordination and mutually beneficial cooperation. Lang \& Hornburg (1998) argued that social capital generally refers to the availability of mutual trust in society (stocks of social trust), norms, and networks that can be utilized by the community to solve common problems.

Coleman (1988) saw social capital as a whole thing directed or created to facilitate individual actions in their social structure. However, Putnam argued that physical capital refers to physical objects and human capital refers to individual property, social capital refers to the relationship between individuals, social networks and the norms of reciprocity and the trust that arises from them. Both Coleman and Putnam both recognize that social capital can increase or decrease over time (Feigenberg et al., 2010). As Coleman and Putnam; Fukuyama (2001) explains that each group has the potential for social capital - the extent to which it is utilized for the radius of trust. Meanwhile, the form of social capital is based. Types of social networks can be distinguished as follows (Woolcock, 2001 in Usman, 2018):

a. Bonding social capital means the bond among people in the same situation, such as close family, close friends, and neighborhood.

b. Bridging social capital includes bonds that are laxer than some people, such as distant friends and coworkers.

c. Linking social capital, reaches people in different situations that are completely outside the community, thus encouraging its members to use more resources available in the community.

Binding social capital tends to encourage exclusive identity and maintain homogeneity while bridging social capital tends to unite from various social domains (Putnam, 2001). Each of these forms can bring together the different needs of each member. Binding social capital is

Copyright (C 2019. Owned by Author(s), published by Society. This is an open access article under CC-BY-NC-SA license. https://doi.org/10.33019/society.v7i2.124

270 
adhesive and reinforces a specific identity (Putnam, 2001). Bridging social capital is a relationship that bridges better in connecting external assets and for the distribution of information and can build a wider identity and reciprocity (Putnam, 2001).

Figure 1

Bonding, Bridging, and Linking Social Capital

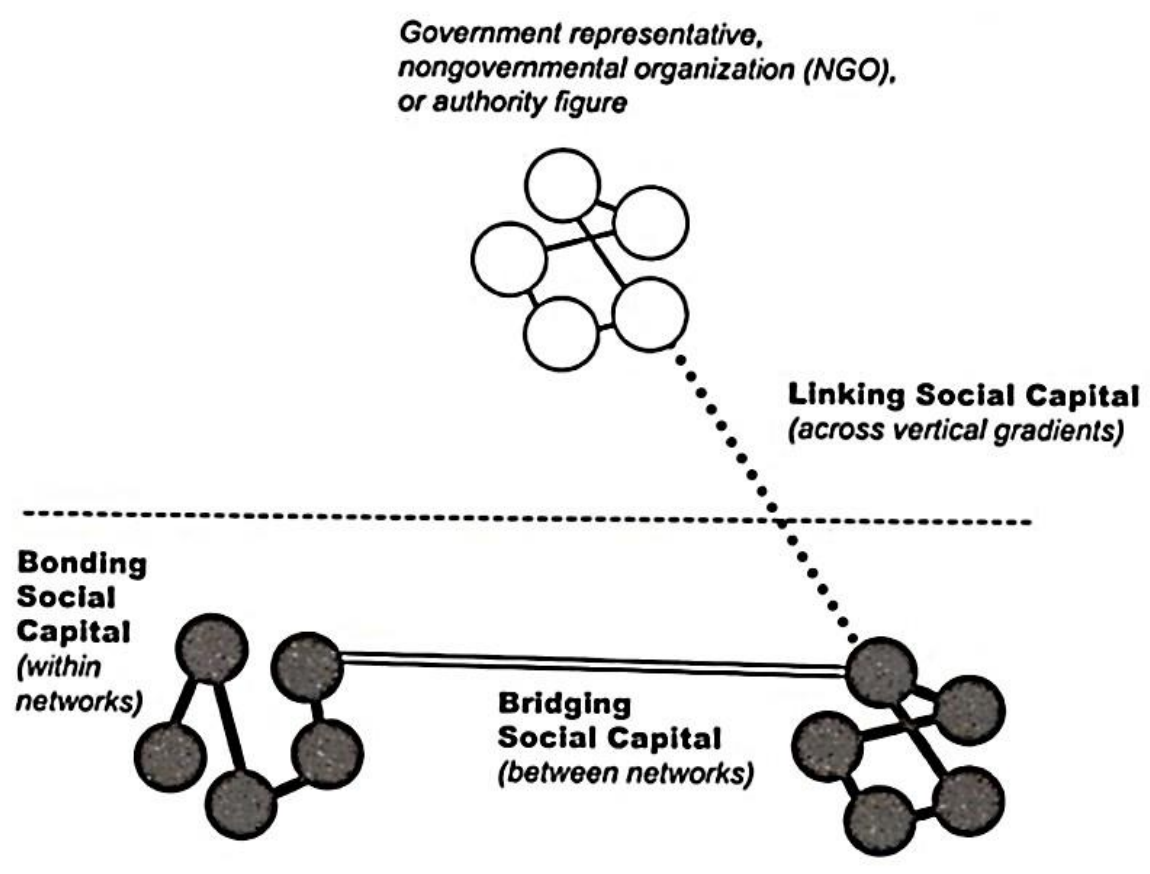

Network A

Network B

Source: (Babaei et al., 2012)

Based on the type of social capital proposed by Woolcock (2001), there is a connection with the problem to be investigated, especially on PKH beneficiary households (KPM) in Sukoharjo district. Where the three types are relevant above, namely social bounding, social bridging and social linking with the role of social capital in managing the potential they have to build a business so that they can get out of poverty and no longer depend on social assistance. This is supported by the existence of solidarity, trust, cooperation, the awareness that supports the importance of improving economic conditions and the existence of $\mathrm{PKH}$ in supporting the social capital mechanisms that they applied.

\section{Research Methodology}

This research was conducted at PKH Sukoharjo district for 10 months, from January 2019 to October 2019. This type of research is qualitative with a case study approach. The technique in determining informants used a purposive sampling of beneficiary households who were still receiving PKH assistance. There were eight beneficiary households from the 2013-2018 membership year. Also supported by four key informants; the Head of Sukoharjo district office of the Ministry of Social Services, coordinator of Sukoharjo district, PKH supervisor, PKH facilitator, and two key informants to support any information. Data collection techniques used were observation, interviews, and documentation. Observation and in-depth interviews were conducted with KPM-PKH. Also, the documentation study techniques were used. 
Source triangulation techniques were used to measure the validity of the data by testing the credibility of the data through observation techniques with interview techniques during the data collection process. This research used an interactive analysis technique that was collecting data both through observation and interviews. Data reduction was by simplifying the data in the field into important finding points that were filtered according to the needs of under the social capital used concepts. The collected data regarding the dimensions of cultural values, dimensions of Trust, reciprocity, participation, dimensions of communication systems and business networks of PKH beneficiary households in Sukoharjo district. The verification or conclusion is a review of the activities of records and data related to the role of social capital in building the independence of PKH beneficiary households in Sukoharjo obtained during the research process in the field. After the data was reinterpreted, then to draw conclusions based on the perspective of Woolcock's social capital theory. The results of this verification have obtained the validity of data.

\section{Results and Discussion}

\section{A. The Role of PKH in Empowering the Beneficiary Households of PKH}

PKH does not only transfer cash to poor households but also assists all PKH beneficiary households. Based on the results of this research, the roles of PKH in empowering beneficiary households are as follows:

\section{1) The Empowerment through Cash Assistance in Improving the Needs of Education and Health}

PKH assistance is given with special prerequisites to poor households and has components including school children/toddlers/pregnant women/elderly/people with disabilities. PKH beneficiary households will receive assistance in nominal terms according to component criteria. For the assistance of elementary school children $\operatorname{Rp} 900,000 /$ year; the middle school is $\operatorname{Rp} 1,500,000 /$ year; the high school in the amount of $\operatorname{Rp} 2,000,000 /$ year; toddlers/pregnant women/elderly/people with disabilities receive assistance $\operatorname{Rp} 2,400,000 /$ year.

Assistance provided has special prerequisites including for school children must attend $80 \%$ of attendance, for toddlers, pregnant women, disability obliged to go to the health center every month for health checks and immunizations. For elderly people are required to poswindu (integrated service post for people above 18 years old) and do health checks every month. In addition to these conditions, the beneficiary households must attend the Family Development Session (P2K2) once a month. If the above conditions are not fulfilled, the sanctions will be in the form of suspension. The assistance will be pending for a while until they are committed again.

The use of aid money must also be appropriate to fulfill the needs of education, health, and nutrition. Some of the beneficiary households, who are good at managing finances, have set aside the fund to run a business. They started to run small businesses and planned that when the business was growing rapidly they would be ready out of $\mathrm{PKH}$ or graduated declared.

The results showed that the assistance helps beneficiary households. They do not need to be indebted to allocate funds for school fees and nutrition. They could use the PKH aid money for to fulfill it. Besides, some beneficiaries allocate the fund for small business. Many have succeeded with their efforts and finally out of the PKH program with a business that is run or commonly known as Graduasi Mandiri Sejahtera. 


\section{The Empowerment of Households towards Independence through Social Capital in Program Keluarga Harapan (PKH)}

\section{2) Empowerment through the Family Development Session (FDS)}

FDS, or better-known P2K2 (Pertemuan Peningkatan Kemampuan Keluarga), is a structured learning process to strengthen behavior change in PKH beneficiary households. In general, FDS aims to increase knowledge, understanding of the importance of education, health and financial management for households. Material presented during FDS is related to health and nutrition issues, care and education, child protection, household financial management, and social welfare.

FDS is expected to change the behavior and mindset of the participants. The changes are expected to lift participants from poverty. With FDS, participants are not only given knowledge by the mentor but also motivation. Each session is held once a month with a duration of 2 to 2.5 hours. Activities are carried out interactively-participatory (not one-way), starting with the opening, reviewing the previous material, as well as the delivery of material and questions and answers.

The benefits of implementing FDS are not only felt in Indonesia. The study from Mexico showed that carrying FDS ("platicas") in Conditional Cash Transfer (CCT) program Oportunidades has contributed to improving health outcomes by encouraging better food consumption (Hoddinott \& Skoufias in Habibullah, 2017) and increasing knowledge in various health issues (Duarte-Gómez et al., in Habibullah, 2017).

Studies from Bangladesh showed that combining cash transfers with behavioral changes encourages a significantly greater impact including greater expenditure on healthy food (milk, meat, eggs, and fish) than if only cash assistance. In Jamaica, the Home Visits Program, this program teaches mothers about childcare for better cognitive development and continually changing behavior (Walker et al., in Habibullah, 2017). In Indonesia, the benefits of FDS are following the results of research conducted in the District of Sukoharjo showed that 1) The implementation of FDS can increase nutritional fulfillment. 2) Able to provide good learning assistance for the child during the learning process. 3) Able to foster an attitude of sympathy and empathy for the elderly and people with disabilities. 4) Able to control the economy by managing the ability to save and careful in borrowing.

The results showed that FDS was considered to improve the ability of beneficiary households in terms of knowledge, attitudes and economic improvements they experienced. Beneficiary households feel that there is a special school for PKH beneficiaries. They feel the benefits of being able to share opinions about the science of daily life which they sometimes take for granted. Besides they feel happy learning in a forum that they are considered to have a close bond that is the same sense of fate. So they are not afraid to express their opinions in discussion forums that are guided by PKH facilitators.

Besides having a function in terms of knowledge, attitude and economic improvement, FDS is also used as a forum for PKH facilitators to educate the importance of building awareness when it is economically capable to conduct graduations (out of $\mathrm{PKH}$ ). In addition to assisting, they also conduct evaluations and monitor households who have experienced economic improvement. Special assistance will be applied to households that have experienced economic improvement. It is intended that beneficiary households realize that PKH assistance is only given to the poor households. For those who are already prosperous, they will graduate soon. It is proven in the Sukoharjo district since 2016-2019 429 households who have successfully graduated or finally out of PKH (Graduasi Mandiri Sejahtera). That means PKH in the Sukoharjo district has successfully contributed to reducing poverty in Indonesia by 429 households $/ 3$ years.

Copyright (C 2019. Owned by Author(s), published by Society. This is an open access article under CC-BY-NC-SA license. 


\section{3) Empowerment through Kelompok Usaha Bersama (KUBE) PKH}

A special program from the government that establishes networks with PKH is Kelompok Usaha Bersama or KUBE (Joint Business Group). This program is a government assistance program in the form of business funds for households of PKH beneficiaries of ten households with funds of $\operatorname{Rp} 20,000,000$. Allocation of the funds is realized in the form of basic food to run a grocery shop or commonly known as E-Waroeng. With prices under the market, the goal of the KUBE PKH is to provide food, especially for the poor households, at prices under the market.

The results showed that the existence of this business process was able to improve the economy of KUBE management, namely PKH beneficiary households. It also provided opportunities for the poor households of PKH or Non-Cash Food Assistance (BPNT) to establish profitable cooperation. PKH beneficiary households, as caretakers, receive profits and other beneficiary households will benefit from low-cost shopping.

KUBE is one embodiment of economic capital provided by the government to beneficiary households, to empower them with the given capital. It is hoped that in the long run, they can get out of PKH so that they do not depend on the assistance provided by the government.

Three support programs organized by PKH Sukoharjo district are the embodiment of empowerment. The target of PKH Sukoharjo Regency is to empower the community with a maximum target for 6 years through the KUBE, Cooperative and assistance programs obtained from PKH. This support is provided in the short term to train beneficiary households to be able to empower themselves independently. With initial assistance and assistance activities, they are expected to be able to run a business with the innovation and creativity of each person. There have been several businesses that developed both in terms of animal husbandry, trade, culinary and agriculture. Those who successfully run the business can finally end of PKH under the predicate Graduasi Mandiri Sejahtera that has contributed to realizing an active community and reducing poverty that occurs in Indonesia.

\section{4) Empowerment through PKH Cooperative}

PKH Cooperative is the only program in PKH Sukoharjo district. It was established since 2014 by the Regent of Sukoharjo. With the presence of this cooperative, which engaged in the field of savings and lending, it was able to empower PKH beneficiary households. The initial

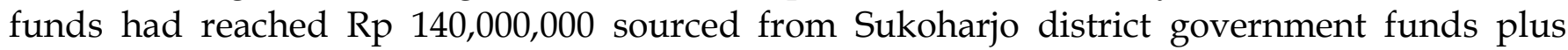
additional basic and mandatory savings funds of PKH beneficiaries.

The existing funds used to provide business capital loans for beneficiary households who already have a business or who want to start running a business under the terms and conditions. So far, in Sukoharjo district, it has been identified that several beneficiary households who have businesses are using PKH cooperative capital loans.

The results showed that cooperative is a solution for the beneficiaries who unwilling access to bank loans since they do not have collateral and feel the bank has high interest. With cooperative, they feel calm when they want to start a business or when they suddenly need money. With low interest and can be repaid in a long time, they can use cooperative funds for various purposes.

With the support of capital funds, which are provided by the Government of Sukoharjo District, specifically for PKH beneficiary households, it can support the occurrence of independent prosperous graduation, which is a household that is capable of having a business. 


\section{B. The Roles of Social Capital in Creating Independence among PKH Beneficiary Households}

The emergence of the PKH is seen as a rescue aid for the poor community. This is inseparable from the concerns of the community in various aspects especially education, health, and social welfare. From the economic aspect, there are still many people in Sukoharjo district who are categorized as poor. Poverty alleviation, which is carried out from the central government to local government, must have a clear command. This important matter needs to be considered so that there will be no turmoil between the beneficiary households. The households are not just dependent but empowered, following the vision of Sukoharjo districts, in carrying out programs from the Ministry of Social Affairs of the Republic of Indonesia. Protection is needed in the distribution of aid and innovation programs carried out by the local government to support PKH. The goal is to have a well-managed PKH that is expected to bring prosperity, improve the economy of beneficiary households so that it can reduce poverty. With improved welfare, institutions and strong social relations, it is hoped that the village will be more independent and stable in developing businesses carried out by the values of culture, trust, reciprocity, participation and communication systems, and business networks. From this aspect, factual findings in the field show the following points:

\section{1) The Dimension of Cultural Value}

A society consisting of individuals is a social creature with the characteristics of a mutual need for one another in his life. Therefore there is a tendency to cooperate and interact with each other including in times of poor conditions where all people need to survive/carry on their lives.

Government assistance activities through PKH empowerment are based on community values and norms as part of the social capital component. The findings of this research indicate that the PKH program adopted the group model to contain several shared consensus or called the 'PKH Member Principles', namely:

a) Determined to improve the quality of life/welfare of PKH beneficiaries;

b) Conducting business through KUBE capital and cooperatives to survive;

c) Discipline and be trusted in order to be trusted in building networks, including in the case of debts and receivables in the PKH;

d) Serious and smart in working to meet the needs of life;

e) Mutual assistance to PKH members when they are in trouble because they feel a sense of fate.

This explanation gives an understanding that the value base and culture developed by PKH beneficiary households in the economic improvement activities is the implication of the willingness to consolidate themselves with parties outside. Also, this dimension of values and culture then becomes the "adhesive" for social interaction among PKH beneficiary households.

\section{2) The Dimension of Trust, Reciprocity, and Participation}

The strength of PKH beneficiary households lies in the aspect of mutual trust and need for the capacities of each household. This is where PKH beneficiary households can exchange information to strengthen their respective roles in carrying out economic improvement activities. Households have an active role as economic actors, namely sellers (business people) and some play an active role as consumers. There is a relationship of trust between PKH members in conducting high-value cooperative loans without collateral. Also, there is a

Copyright (C 2019. Owned by Author(s), published by Society. This is an open access article under CC-BY-NC-SA license.

https://doi.org/10.33019/society.v7i2.124

275 
relationship of trust between PKH facilitators and beneficiaries in providing KUBE capital selected based on entrepreneurial skills and expertise. This shows that there is a steady bond that causes a high sense of trust in establishing economic relations.

There is also a reciprocal relationship between the government in providing programs and poor households as program recipients. The mutual relationship that is established is to provide education for the beneficiary households to be independent prosperous and able to create resilience in living. In the end, $\mathrm{PKH}$ beneficiary households can actively participate in their communities which are expected to be well-maintained in the long run. The reciprocal relationship between the government and the beneficiaries is that the beneficiaries get capital gains and experience a more prosperous life with the business they run. The government also receives a profit that can reduce unemployment and poverty by providing capital to $\mathrm{PKH}$ beneficiary households. So indirectly this relationship is considered to be an abstract symbiotic mutualism.

With the benefits gained; it causes an extraordinary growth of participation from beneficiaries. They became enthusiastic about the PKH assistance process. They assume that the assistance they get will bring long-term benefits to their lives. The participation of Sukoharjo district government in order to empower the PKH beneficiary households is also not inferior. They seek and mobilize regional funds to conduct a superior program namely $\mathrm{PKH}$ Cooperative. With the aim that people feel benefited and not caught with bank interest expense. Government funds for the people are ultimately able to encourage the poor community to start a business.

\section{3) The Dimension of the Communication System and Business Network}

Good relations between actors (PKH, Sukoharjo district office of the Ministry of Social Services, and Sukoharjo district government) can provide benefits to households of PKH beneficiaries. The communication system here is an open relationship when experiencing difficulties in terms of the economy, life and when running a business. This can be facilitated through PKH facilitators or other stakeholders such as Sukoharjo district office of the Ministry of Social Services. The assistance provided is intended to enable beneficiary households to be able to take advantage of the opportunities available to establish a business. The effort was carried out with the support of PKH and local stakeholders. Their business capabilities not only include internal PKH communities but also external parties outside the PKH community.

So with a good communication system between stakeholders and PKH beneficiaries can minimize the problems that arise in handling poverty and running a business. Routine coordination that continues to be carried out by PKH facilitators and business actors in PKH can increase the confidence of PKH business actors.

Furthermore, the form of social capital provided by $\mathrm{PKH}$ in creating a network of independence, which is supported by the relevance of bonding social capital, bridging social capital, and linking social capital following social capital theory proposed by Woolcock (2001). Below is a figure of the relevance: 
Figure 2

Social Capital Model of Beneficiary Households to Build Dependence

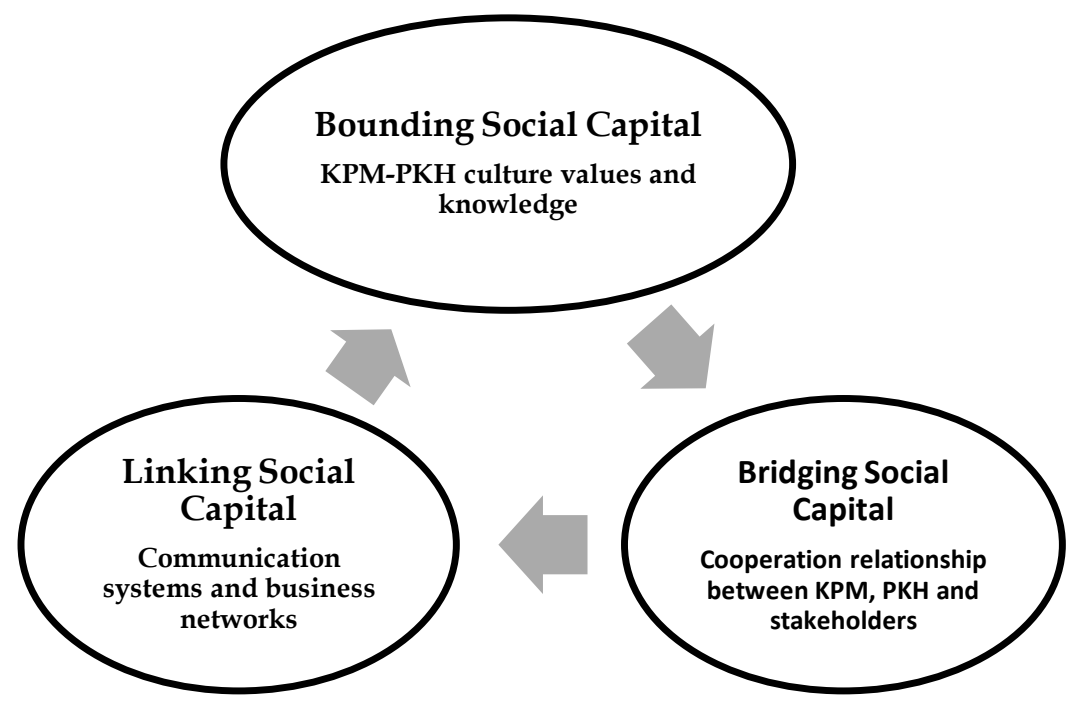

Source: (Primary Data, 2019)

The figure above shows that the three levels of social capital provide an understanding that social capital can contribute to social integration while addressing the economic problems of the poor in creating self-reliance. In this case when looking at the mechanism of relations between actors involving PKH facilitators related to the assistance program. First, bonding social capital is grown through the meaning of the Family Development Session (FDS). This is caused by the ability of FDS in building cultural values and honing the ability of households to increase knowledge and empower themselves.

Second, the bridging social capital in this section is established a cooperative relationship between KPM, PKH, and stakeholders in improving their economy. A reciprocal relationship that is mutually beneficial and mutually supportive of one another. This was established in the contribution of regional stakeholders in providing the $\mathrm{PKH}$ Cooperative program. Here not only from PKH that is given benefits but the local government is also benefited in the form of increased income of the community through the business undertaken. So that local government achievements to reduce poverty through business independence is considered successful.

Third, linking social capital is established because of the communication system and business network owned by PKH beneficiary households. With good communication between actors, they can grow their KUBE business network. The network is in the form of mutual benefit or commonly called symbiotic mutuality. Because they are inter-family roles as producers and some are consumers. The relationship is established continuously between beneficiary households. The same feeling, the same fate makes a marketing system that can control the market of the beneficiaries between the districts. Thus, they can empower themselves with the business they run, which begins with the circumference of the business of fellow beneficiary households. More than that, they are also able to market their products to the wider community. But all this cannot be separated from the basis of values and trust, which then continues to work together as an element of reciprocity.

Strengthening the role of social capital in a business or improving the household economy, is inseparable from the effort of cooperative relations among actors who have common interests. Actors who play a role are PKH beneficiary households who have a common interest 


\section{The Empowerment of Households towards Independence through Social Capital in Program Keluarga Harapan (PKH)}

in obtaining PKH social assistance. Cooperation starts from kinship relations; the main route used by individual interests towards social cooperation is kin selection, kinship relations, and reciprocity among $\mathrm{PKH}$ beneficiaries.

The dimensions of values, culture, and perception are built as the initial foundation to collect common interests in the form of institutions, which consist of fellow $\mathrm{PKH}$ beneficiaries communities; cooperative; and KUBE PKH through the facilitation of assistance from $\mathrm{PKH}$. Thus, the role of social capital in improving the economics of beneficiary households is strategic in overcoming the complexity of the existing problems. Established solidarity can come up with useful solutions collectively. Also, social capital, in the understanding of community development studies, is important as an analytical reference for the application of development programs.

Thus, independence arises from the support of programs and the social capital they have. This makes the beneficiaries households within less than 6 years expected to be empowered without PKH social assistance anymore. It was proven in the Sukoharjo district since 2016-2019 429 households succeeded in becoming independent prosperous graduation, meaning that there were 429 beneficiaries, who were economical, capable by running a business. So PKH in Sukoharjo district succeeded in contributing to reduce poverty in Indonesia by 429 households/3 years.

\section{Conclusions}

The PKH or Family of Hope Program can improve the condition and situation of the beneficiary households. The empowerment of poor households in the Sukoharjo district is strongly influenced by the existence of $\mathrm{PKH}$ and its implementation. Beneficiary households can use PKH to increase their access to public services, improve the quality of education and health of household members, increase social support, increase household economic activities, and improve patterns of problem-solving in the household.

Concerning the effort to increase the independence of $\mathrm{PKH}$ beneficiary household, it turns out that it becomes a necessity to be handled holistically, especially for policymakers by utilizing all existing potentials, including the potential for social capital. This becomes important, considering that the aspect of household economic empowerment becomes an entry point for advancing community welfare. The implementation of various policies and programs that are oriented towards household economic empowerment should be appreciated in its role of providing opportunities for access especially for the poor community so that they can improve the quality of livelihood. Thus, household empowerment which involves a cultural dimension and utilizing the role of social capital in the community can optimize the results of the empowerment process.

Social capital of PKH has a component that contains trust, values and social norms, reciprocity which is the foundation of the mechanism and forms a cooperative institution that can be utilized to strengthen the economy of $\mathrm{PKH}$ beneficiary households. Financial limitations can be overcome by them by utilizing social networking opportunities in the form of social gathering, KUBE PKH forums, and cooperatives based on mutual trust. This condition makes access to economic resources for poor households more open which fully relies on good relations so that the households' economy can survive and there is an increase. Thus, the position of poor households as weak figures has now succeeded in exploiting the potential of social capital. Hopes for the future with the harmony of the social capital of beneficiary

Copyright (C 2019. Owned by Author(s), published by Society. This is an open access article under CC-BY-NC-SA license.

https://doi.org/10.33019/society.v7i2.124

278 
households able to create independent prosperous graduation and able to live without PKH social assistance (Graduasi Mandiri Sejahtera).

\section{Acknowledgement}

The authors would like to thank the Sebelas Maret University for support and facilities for making this research a success. The authors also wish to thank all informants who have provided help and information during this research conducted.

\section{References}

Alatas, V., Cahyadi, N., Ekasari, E., Harmoun, S., Hidayat, B., Janz, E., \& Jellema, J. (2011). Program Keluarga Harapan: main findings from the impact evaluation of Indonesia's pilot household conditional cash transfer program. New York: World Bank.

Babaei, H., Ahmad, N., \& Gill, S. S. (2012). Bonding, bridging and linking social capital and empowerment among squatter settlements in Tehran, Iran. World Applied Sciences Journal, 17(1), 119-126.

Badan Pusat Statistik. (2018). Statistik Indonesia 2018. Jakarta: Badan Pusat Statistik Indonesia. Retrieved from https://www.bps.go.id/publication/2018/07/03/5a963c1ea9b0fed6497d0845/statistikindonesia-2018.html

Cahyadi, N., Hanna, R., Olken, B. A., Prima, R. A., Satriawan, E., \& Syamsulhakim, E. (2018). Cumulative impacts of conditional cash transfer programs: Experimental evidence from Indonesia (No. w24670). National Bureau of Economic Research.

Coleman, J. S. (1988). Social capital in the creation of human capital. American Journal of Sociology, 94(Suppl 95), S95-S120.

Dulkiah, M., Sari, A. L., \& Irwandi, I. (2018). The Impact of Conditional Cash Transfer (CCT) to Socio-Economic of Poor Families; A Case Study. Jurnal Ilmu Sosial Mamangan, 7(1), 32-39.

Feigenberg, B., Field, E. M., \& Pande, R. (2010). Building social capital through microfinance (No. w16018). National Bureau of Economic Research.

Fukuyama, F. (2002). Social capital and development: The coming agenda. SAIS review, 22(1), 23-37.

Habibullah, H. (2017). Perlindungan Sosial Komprehensif di Indonesia. Sosio Informa, 3(1).

Kholis, N. (2019). Analisis Implementasi Kebijakan Pengentasan Kemiskinan Melalui Program Keluarga Harapan (PKH) di Kecamatan Tanah Merah Kabupaten Bangkalan (Doctoral Dissertation). Surabaya: Universitas Airlangga.

Lang, R. E., \& Hornburg, S. P. (1998). What is social capital and why is it important to public policy?. Housing policy debate, 9(1), 1-16.

Lobo, A. N. (2019, March). Empowering Poor Families through Conditional Cash Transfer in Papua. In Social and Humaniora Research Symposium (SoRes 2018). Atlantis Press.

Luthfi, M. (2019). Efektifitas Bantuan Sosial Program Keluarga Harapan Dalam Meningkatkan Kesejahteraan Keluarga (Studi Kasus Di Desa Margajaya Kecamatan Ngamprah KBB). CommEdu (Community Education Journal), 2(1), 81-89.

Ritzer, G. (Ed.). (2004). Encyclopedia of social theory. Sage publications.

Permana, A. C., Sasmito, C., \& Gunawan, C. I. (2018). Implementasi Pemberdayaan Masyarakat dalam Program Keluarga Harapan untuk Memutus Rantai Kemiskinan di Kota Malang. Madani Jurnal Politik dan Sosial Kemasyarakatan, 10(2), 64-74. 
Portes, A. (1998). Social capital: Its origins and applications in modern sociology. Annual review of sociology, 24(1), 1-24.

Putnam, R. (2001). Social capital: Measurement and consequences. Canadian journal of policy research, 2(1), 41-51.

Septiani, D., Nurmalisa, Y., \& Halim, A. (2019). Peran Pendamping Program Keluarga Harapan Dalam Membantu Kemandirian Dan Kesejahteraan Keluarga. Jurnal Kultur Demokrasi, $5(1)$.

Simanjuntak, M. (2010). Faktor-faktor yang mempengaruhi kesejahteraan keluarga dan prestasi belajar anak pada keluarga penerima Program Keluarga Harapan (PKH). Bogor: Institut Pertanian Bogor.

Usman, S. (2018). Modal Sosial. Yogyakarta: Pustaka Pelajar.

Woolcock, M. (2001). The place of social capital in understanding social and economic outcomes. Canadian journal of policy research, 2(1), 11-17.

\section{About the Authors}

1. Widia Lestari, a graduate student of Master Program of Sociology, Faculty of Social and Political Sciences, Sebelas Maret University, Indonesia.

E-Mail: widiayayak@gmail.com

2. Drajat Tri Kartono, obtained his Doctoral Degree in Sociology from University of Indonesia, in 2002. The author is an Associate Professor at the Department of Sociology, Faculty of Social and Political Sciences, Sebelas Maret University, Indonesia.

E-Mail: unsdrajat@gmail.com

3. Argyo Demartoto, obtained his Doctoral Degree in Sociology from Gadjah Mada University, in 2012. The author is an Associate Professor at the Department of Sociology, Faculty of Social and Political Sciences, Sebelas Maret University, Indonesia.

E-Mail: argyodemartotofisip@staff.uns.ac.id

4. Khabib Bima Setiyawan, a graduate student of Master Program of Sociology, Faculty of Social and Political Sciences, Sebelas Maret University, Indonesia.

E-Mail: setiyawankhabibbima@gmail.com 